\title{
HARASSMENT IN THE WORKPLACE: THE LEGAL CONTEXT
}

\section{Graeme Lockwood}

King's College London

University of London

150 Stamford Street, London

Tel.: 02078484441

E-mail: graeme.lockwood@kcl.ac.uk

Vidushi Marda

School of Law, Christ University

29 Hosur Road, Bangalore

Tel.: +919986092252

E-mail: vidushi.marda@law.christuniversity.in

Received on 18 May 2014, accepted on 18 September, 2014

doi:10.13165/JUR-14-21-3-02

\section{Introduction}

The occurrence of harassing behaviour in the work environment has been discussed in a variety of literature ${ }^{1}$. Harassment manifests itself in different

1 Ironside, M., and Seifert, R. Tackling Bullying in the Workplace: The Collective Dimension. In: S. Einarsen et al. (eds.). Bullying and Emotional Abuse in the Workplace: International Perspectives in Research Practice. London: Taylor and Francis, 2003, p. 383-398; Keashly, L., and Jagatic, K. By Any Other Name: American Perspectives on Workplace Bullying. In: S. Einarsen et al. (eds.). Bullying and Emotional Abuse in the Workplace: International Perspectives in Research and Practice. London: Taylor and Francis, 2003, 31-61; Salin, D.

Jurisprudencija/Jurisprudence

(C) Mykolo Romerio universitetas, 2014

(C) Mykolas Romeris University, 2014
ISSN 1392-6195 (print), ISSN 2029-2058 (online) http://www.mruni.eu/lt/mokslo_darbai/jurisprudencija/ http://www.mruni.eu/en/mokslo_darbai/jurisprudencija/ 
behaviours, such as social isolation, silent treatment, rumours, false accusations, threats, ridicule, name calling attacking the victim's private life or attitudes, excessive criticism, monitoring of work, withholding information or depriving responsibility and physical or verbal aggression ${ }^{2}$.

There is widespread evidence that harassing conduct can cause a wide range of psychological and work-related harm, including diminished work performance, lower job satisfaction, absenteeism, career interruptions, job loss, depression, and health problems ${ }^{3}$. This article examines case law pursuant to anti-discrimination law and cases brought under the ambit of the Protection from Harassment Act 1997 (PHA, 1997). Information on the flow of interpretive case law will no doubt continue to capture the attention of human resource professions who need to be aware of potential legal liability in this domain.

Frost ${ }^{4}$ has deployed the term 'toxic workplace' to describe the increase in harassing behaviour within organisations, and Hunt et al. ${ }^{5}$ have observed that if

Ways of Explaining Workplace Bullying: A Review of Enabling, Motivating and Precipitating Structures and Processes in the Work Environment. Human Relations. 2003, 56(10): 12131232; Lamertz, L.M., and Aquino, K. Social Power, Social Status and Perceptual Similarity of Workplace Victimisation: A Social Network Analysis of Stratification. Human Relations. 2004, 57(7): 795-822; Lopez, S.H.; Hodson, R., and Roscigno, V.J. Power Status and Abuse at Work: General and Sexual Harassment Compared. Sociological Quarterly. 2009, 50(1): 3-27; Deery, S.; Walsh, J., and Guest, D. Workplace Aggression: The Effects on Job Burnout and Turnover; Intentions. Work, Employmemt and Society. 2013, 25(4): 742-759; Samani, K. Embracing New Directions in Workplace Bullying Research: A Paradigmatic Approach Journal of Management Inquiry. 2012, 22(16): 26-36.

2 Einarsen, S. Bullying and Harassment at Work: Epidemological and Psychosocial aspects. Doctoral dissertation. Department of Psychosocial Science, University of Bergen, 1996; Keashly, L., and Jagatic, K. By Any Other Name: American Perspectives on Workplace Bullying. In: S. Einarsen et al. (eds.). Bullying and Emotional Abuse in the Workplace: International Perspectives in Research and Practice. London: Taylor and Francis, 2003, p. 31-61; Salin, D. Ways of Explaining Workplace Bullying: A Review of Enabling, Motivating and Precipitating Structures and Processes in the Work Environment. Human Relations. 2003, 56(10): 12131232; Deery, S.; Walsh, J., and Guest, D. Workplace Aggression: The Effects on Job Burnout and Turnover Intentions. Work, Employment and Society. 2013, 25(4): 742-759.

3 Keashly, L., and Jagatic, K. By Any Other Name: American Perspectives on Workplace Bullying. In: S. Einarsen et al. (eds.). Bullying and Emotional Abuse in the Workplace: International Perspectives in Research and Practice. Taylor and Francis, 2003, p. 31-61; Leymann, H. The Content and Development of Mobbing at Work. European Journal of Work and Organisational Psychology. 1996, 5(2): 165-184; Vartia, M. Consequences of Workplace Bullying with Respect to the Well-being of Its Targets and the Observers of Bullying. Scandinavian Journal of Work Environment Health. 2001, 27(1): 63-69.

4 Frost, P.J. Toxic Emotions at Work. Boston, MA: Harvard Business School, 2003.

5 Hunt, C.; Davidson, C.; Fielden, S., and Hoel, H. Sexual Harassment in the Workplace: A Literature Review. Equal Opportunities Commission, Working Paper series, No. 59. London, 2007. 
management allows a climate of disrespect to exist within an organisation, this makes it more likely for certain inappropriate behaviour to be taken for granted, and leads to the creation of an 'incivility spiral'.

Samani ${ }^{6}$ has identified harassment pivoting around specific themes, which include: i) harassment based on a misuse or abuse of power; ii) harassment for a discriminatory reason; iii) harassment due to a personality clash; iv) harassment arising as a result of poor management practice; $v$ ) harassment based on characteristics of the victim; vi) harassment borne out of an interaction between individual and situational factors (uncomfortable work environment).

However, whilst the literature referred to is peppered with discussions of the forms harassment might take and the organisational dynamics giving rise to such conduct, there has been a dearth of literature discussing the legal claims made relating to harassment. This research will identify which are the most prominent categories resulting in legal action; lessons for litigants in terms of success or failure of the legal action; consequences for the respective parties of the outcome of legal proceedings and information about the organisational context giving rise to harassment litigation.

In this respect, the work will make important contribution to the existing literature. It will utilise the Samani categories of harassment to identify the most common categories of legal challenge. It will consider the extent to which legal cases fall into the six categories outlined by Samani ${ }^{7}$. Harassing behaviour is often thought to constitute repeated, persistent and continuous conduct; typically single negative acts are not considered harassment ${ }^{8}$. However, in respect of U.K. law, the requirement for a continuous element to the behaviour is not always required. Under discrimination law one single incident can constitute harassment, whereas in cases brought pursuant to the PHA 1997 conduct must be repeated. A qualitative analysis of case law can reveal the events and processes that led up to a harassing claim, the responses of the parties involved and the outcome of the situation.

\section{Legal protection from harassment in the workplace}

A significant number of harassment situations that arise in the work environment can be challenged under the relevant provisions of the Equality Act 2010, where they involve discrimination relating to one of the protected characteristics. The current

6 Samani, K. Embracing New Directions in Workplace Bullying Research: A Paradigmatic Approach. Journal of Management Inquiry. 2012, 22(16): 26-36.

7 Samani, K., supra note 6, p. 26-36.

8 Einarsen, S., and Skogstad, A. Bullying at Work: Epidemiological Findings in Public and Private Organisations. European Journal of Work and Organization Psychology. 1996, 5(2): 185-201. 
provisions relevant to harassment are set out in section 26 of the Equality Act 2010 $(\mathrm{EqA})^{9}$.

However, in some situations redress under discrimination law will not be possible, for example, where the time limit for bringing discrimination proceedings has been exceeded or the harassment asserted is not related to a protected characteristic. This might arise if person A was harassed by person $B$ because of a personality clash rather than some personal characteristic based on sex, race, religion, sexual orientation, disability or age. In this context, discrimination law does not provide a remedy.

The PHA creates a statutory tort of harassment. Under section 3 of the PHA, anyone who is, or who may be, the victim of harassment under the PHA may bring a civil claim for compensation against the employee, or employer, if the harassment took place in the course of employment. Under the PHA 1997 section 1, a person must not pursue a course of conduct, (a) which amounts to harassment of another, and (b) which he knows or ought to know amounts to harassment of the other. For the purposes of this section, the person whose course of conduct is in question ought to know that it amounts to harassment of another if a reasonable person in possession of the same information would think the course of conduct amounted to harassment of the other. Under section 2(1), conduct in breach of section 1 is an offence. Section 2(2) states that this offence is summarily triable with a maximum of six months imprisonment and/or a level 5 fine. Section 3 provides that a person who

9 The EqA 2010, s.26 provides:

(1) A person (A) harasses another (B) if-

(a) A engages in unwanted conduct related to a relevant protected characteristic, and

(b) the conduct has the purpose or effect of-

(i) violating B's dignity, or

(ii)creating an intimidating, hostile, degrading, humiliating or offensive environment for B.

(2) A also harasses B if-

(a) A engages in unwanted conduct of a sexual nature, and

(b)the conduct has the purpose or effect referred to in subsection (1)(b).

(3)A also harasses B if-

(a) A or another person engages in unwanted conduct of a sexual nature or that is related to gender reassignment or sex,

(b) the conduct has the purpose or effect referred to in subsection (1)(b), and

(c) because of B's rejection of or submission to the conduct, A treats B less favourably than A would treat B if B had not rejected or submitted to the conduct.

(4) In deciding whether conduct has the effect referred to in subsection (1)(b), each of the following must be taken into account-

(a) the perception of $\mathrm{B}$;

(b) the other circumstances of the case;

(c) whether it is reasonable for the conduct to have that effect.

(5) The relevant protected characteristics are - age; disability; gender reassignment; race; religion or belief; sex; sexual orientation. 
is or may be the victim of a course of conduct amounting to harassment can bring a civil action. This claim will be heard in the County Court or the High Court. The Court can award damages, including damages for anxiety, and any resulting financial loss. The victim or potential victim can also ask the Court to grant an injunction restraining the person from any conduct that amounts to harassment. If the person does anything, which is prohibited by that injunction, he or she can be sentenced to imprisonment for contempt of the Court. The level and degree of protection provided under the Act depends on how the courts interpret and apply (a) which amounts to harassment of another, and (b) which he knows or ought to know amounts to harassment of the other.

In what is considered a landmark case Majrowski v. Guy's \& St Thomas' NHS Trust $[2005]^{10}$, a clinical audit coordinator for an NHS trust alleged that he was harassed at work by his department manager, partly due to his sexual orientation. He brought a claim for damages against his employer under section 3 of the PHA 1997, claiming that it was vicariously liable for the behaviour of the manager who harassed him. His claim was struck out at first instance on the grounds that the PHA 1997 does not permit vicarious liability. However, the Court of Appeal held that an employer may be held vicariously liable for harassment by its employees, in breach of the PHA 1997, provided that there is a sufficiently clear link between the work and the harassment. The NHS Trust was caught in a pincer forged from the harassing conduct of the employee and an expanded conception of vicarious liability ${ }^{11}$. In an employment context, the PHA 1997 might provide an avenue of relief where a person is subject to harassment outside work by a colleague or a manager.

The decision was significant as it extended the claims that an employee could bring against their employer if they felt that they had been the victim of harassment. Prior to this decision, an employee was limited to bringing claims of discrimination and/or negligence. Following Majrowski, employees could bring harassment claims where there has been conduct which has occurred on at least two occasions, which is targeted at the victim, where they have suffered alarm, anxiety or distress, and where the conduct complained of is 'oppressive and unacceptable', not merely 'unreasonable' (Lord Nicholls).

\section{Method}

This paper focuses on legal claims pertaining to harassment. The term claimant is used to refer to the worker who made the original complaint of harassment, and the term respondent refers to the employing organisation defending the claim. Given

10 Majrowski v. Guy's \& St Thomas' NHS Trust [2006] UKHL 34

11 Williams, K. Vicarious Liability of the Roman Catholic Church for Sexual Abuse by a Priest. Journal of Professional Negligence. 2010, 26: 113-117. 
that part of this study examines appellate cases, it is important that these particular findings are set in context. Appeal cases are both important and atypical. The appellate cases tend to deal with questions of law, which may make these cases particularly pertinent and different from the run of the mill harassment cases heard by the court of first instance the employment tribunal. However, the appellate cases also provide a detailed review of the first instance hearing in the employment tribunal and identify the key legal and factual issues. The population of individual case records with a harassment component was accessed electronically from a variety of legal databases. A stratified-random sample of one hundred and sixty cases implicating harassment was subject to the analysis.

\section{Harassment cases brought under anti-discrimination law}

One hundred and sixty harassment cases were selected for the analysis. In respect of the types of harassment, the majority of claims made were related to sex discrimination (67), followed by racial harassment (55), disability harassment (28) and age related harassment (5). Many sex, race and disability harassment cases concerned an uncomfortable work environment and/or a misuse or abuse of power. Twenty percent of claimants held administrative/secretarial positions, and twenty percent were in occupations relating to sales/customer service. Interestingly, twelve percent of claimants were senior managers or officials and this class of claimant was also least successful - having a win rate of only 8 percent.

Forty- nine percent of claimants won cases, while fifty percent lost. Where the nature of harassment complained of was physical, the success rate of claimants was higher than where the harassment complained of was only verbal. A plausible explanation for this might be that it is harder to prove verbal harassment, as sometimes general unpleasantness may be construed as harassment by the complainant, but the tribunals do not go as far as to equate the two. Organisational cultures involving administrative or hierarchical structures were more prone to harassment and bullying as compared to professional occupations.

Tribunals were more receptive and favourable to claimants who had already filed an internal complaint or raised an issue about the harassment alleged, prior to coming before the tribunal. This seems to have lent credibility to the claimant's case. In some cases, if the tribunal was convinced that the claimant had either come before it in haste or had been slow in doing so, the entire case was set aside ( $A$ Ghosh $v$. Nokia Siemens Network UK Limited $)^{12}$. Claimants who raised formal grievances and took action within the organization were taken more seriously than claimants who resorted to legal action at the first instance. The conduct of claimants in this 
respect was kept in mind of tribunals while deciding cases, some tribunals focused on whether the employee had complained about the harassment ${ }^{13}$. This ignored the reality faced by victims of harassment who did not want to risk being labelled a troublemaker, damaging their career, not being believed, or simply hoping the harassing behaviour would cease.

Since most cases before tribunals came down to whose version of events the tribunal believed, the certainty and clarity with which a case is narrated by the claimant is of paramount importance. In some cases, claimants meticulously kept a diary of events as they occurred and confided in an authority at the relevant time and this was well regarded by tribunals. The courts also placed significance on whether or not the claimant had made their discomfort/distress known to the defendant. If this indeed had happened and the harassing behaviour ended after that, the courts generally took a lenient position as to the defendant.

Claimants who brought no additional claims were most successful, and the success rate was found to be inversely proportional to additional claims brought. The tribunals appreciated concise complaints and responded adversely to exaggerated and vague complaints.

Further, organizations that had an equal opportunities policy that provided a formal mechanism for redress of grievances were much more likely to be avoid liability as compared to an organization that did not.

Even if organizations had indeed looked into the matter an informal "admonishment" by a person of authority or an informal investigation was not generally accepted by the courts as being sufficient to show that all efforts had been taken to avoid such harassment. Courts hold employers to a relatively high standard once a complaint was made, an actual change in the work environment and an actual enhancement of the victim's level of comfort were taken seriously. Incivillity and bullying flourish in unsupportive work groups and normalise competitive and abusive behaviours ${ }^{14}$.

The analysis of race harassment cases detected that claims were often based on the fact that the claimant had endured a prolonged period of racist behaviour that the employer had not tackled adequately. This finding is consistent with the research of Aston, Hill and Tackey, who found that many race discrimination claims to employment tribunals originated from management failure to support employees' complaints of racist behaviour from employees and clients ${ }^{15}$.

13 Lockwood, G. A Legal Analysis of Sexual Harassment Tribunal Cases 1995-2005. International Journal of Law and Management. 50(6): 316-332.

14 Feblinger, D.M. Incivility and Bullying in the Workplace and Nurses Shame Responses. Association of Women's Health, Obstetric and Neonatal. 2008, 37(2): 234-242.

15 Aston, J.; Hill, D., and Tackey, N.D. The Experience of Claimants in Race Discrimination Employment Tribunal Cases. Employment Relations Series No.55, DTI London, 2006. 
Disability harassment cases often originate from inappropriate attitudes being displayed by co-workers towards the disabled. Effective disability awareness training appears to be lacking in both public and private sector organisations to challenge such behaviour/attitudes. For example, in one case an employee was regularly ridiculed and bullied by co-workers about his speech defect, the employer was held liable for the harassment for failing to take measures to stop the behaviour. This reflects the findings of the Equality and Human Rights Commission, which found that harassment is a commonplace experience for disabled people, but a culture of disbelief and systemic institutional failures is preventing it from being tackled effectively (EHRC, 2013, p. 3) ${ }^{16}$.

In relation to age discrimination cases, the majority of cases involved claims from older workers rather than younger persons, although one case involved a claim from an 18 year old who endured derogatory remarks about being a teenager. The majority of claims related to older workers who had suffered from age harassment in the form of ageist jokes and other remarks aimed at them by supervisors or work colleagues. The cases were often based on initial 'joking' behaviour that subsequently mushroomed out of control, resulting in the claimant feeling hurt and isolated. There were also several cases where managers had instituted discriminatory practices designed to force an old worker out of the workplace.

In summary, claims brought under the discrimination law sphere are often based on injury to feelings arising from a claimant being made to feel uncomfortable in the work environment or as a result of an abuse of power, commonly based around sex, race, or disability harassment.

\section{Harassment cases brought under the Protection of Harassment Act 1997}

To date, nine cases of harassment related to the work context have been brought under the PHA 1997. Five claims were rejected and four cases were upheld. Utilising the Samani ${ }^{17}$ categories of harassment to identify the most common categories of legal challenge: i) harassment based on a misuse or abuse of power; ii) harassment for a discriminatory reason; iii) harassment due to a personality clash; iv) harassment arising as a result of poor management practice; $v$ ) harassment based on characteristics of the victim; vi) harassment borne out of an interaction between individual and situational factors (uncomfortable work environment), it was found that two cases related to an abuse of power, four cases related to a clash of personalities, one case related to management failings, and seven cases related to harassment borne out of

16 Equality and Human Rights Commission. Manifest for Change Progress Report. London, 2013.

17 Samani, K., supra note 6, p. 26-36. 
an interaction between individual and situational factors. In cases brought under the PHA, the majority of cases involved more than one of Samani's themes.

Whilst the nature of the problem that the Act was introduced to tackle was the stalking of women, it is clear that the Act has a wider ambit than that (Lord Rix, Iqbal v Dean Manson Solicitors [2011], para. 1, p. 2) ${ }^{18}$ and has a direct application to workplace harassment. It is possible for a range of behaviour and conduct perpetuated in the workplace to be regarded as "course of conduct" under the Act. Even if there is a reasonable interval between the incidents, this may not prevent an employee bringing a claim ${ }^{19}$. Green $v$. DB Group Services ${ }^{20}$ illustrates that many incidents viewed in isolation would amount to no more than unpleasant behaviour, but it is their cumulative effect that has to be considered. In this case, much of the behaviour that the victim was subject to might be viewed as childish and petty, but dealing with it on a daily basis had a serious, cumulative psychological impact. Such conduct gave rise to a foreseeable risk of psychiatric injury that an employer should have taken steps to prevent. This particular case was a good example of how vindictive and spiteful behaviour can be 'contagious' and spread among a workgroup within an organisation ${ }^{21}$. Harassing behaviour established under the PHA often reflected a form of psychological harassment and emotional aggression disturbing the workplace norm of mutual respect ${ }^{22}$. In terms of the impact on the victim, the majority of claimants alleged to be suffering from severe depression or stress disorders as a result of the conduct endured.

For a PHA claim to be sustained in a workplace setting, harassment must be established, going beyond unpleasant and unreasonable behaviour, and be likely to produce the consequences of anxiety, alarm or distress.

Cases brought under the PHA tended to centre around the fact that: (i) the harassing behaviour arose because the perpetrator disliked something about the personality or character of the victim; (ii) the harassing behaviour was prompted because of a work related issue, for example, drawing management attention to the poor working practices of co-workers (in these circumstances, the response of

19 Hay, G. The Protection of Harassment Act 1997.2012 [interactive]. [accessed on 07-09-2012]. $<$ www.personneltoday.com/Articles/03/01/2012/58253/Legal>; Keen, S. Developments in the Law of Harassment in 2009. 2009 [interactive]. [accessed on 12-04-2012]. <www. pumpcourtcpd.com $\geq$.

20 Green v. DB Group Services [2006], EWHC,1898 (QB).

21 Glomb, T.M., and Liao, H. Interpersonal Aggression in Work Groups: Social Influence, Reciprocal and Individual Effects. Academy of Management Journal. 2003, 46(4): 486-705; Deery, S.; Walsh, J.,and Guest, D. Workplace Aggression: The Effects on Job Burnout and Turnover Intentions. Work, Employment and Society. 2013, 25(4): 742-759.

22 Feblinger, D.M. Incivility and Bullying in the Workplace and Nurses Shame Responses. Association of Women's Health, Obstetric and Neonatal. 2008, 37(2): 234-242. 
management can be crucial to ensuring that incidents do not escalate out of hand); (iii) a number of cases involved the improper exercise of power with a stronger party being accused of unfairly treating a weaker party in the work context.

The analysis of court decisions revealed that in cases that were lost by the employer, it was evident that there was a culpable want of care on the part of either a line manager or HR department. There was evidence of a failure to deal with longstanding problems or a failure to undertake investigations into bullying when complaints were made. In many cases, the employing organisation failed across an extended period to pay proper attention to complaints from victims of harassment in the workplace

In contrast, in some appellate-level cases, the Court of Appeal commented negatively on some claimants who took multiple claims arising out of the same incidents; the claimant in one case, in addition to the PHA case, took actions for wrongful dismissal, unfair dismissal, and sexual harassment in the employment tribunal. In the mind of the Court of Appeal, the multiple claims undermined the credibility of the claimant, suggesting it was unfounded and speculative in nature.

An important finding unearthed in the case analysis was that the majority of claimants had made a complaint to the organisation about harassing behaviour, but that the complaint was not properly dealt with. The result was that the problem festered, the situation escalated, and the legal action ultimately commenced.

It is clear that developments in respect to legal actions based on the PHA should prompt organisations to consider making changes to HR policies. It would be in employing organisations' interests to develop procedures to identify and deal with worker conflict and worker grievances. This is particularly the case given the consequences that the harassment can have for the victim. It is often asserted that the harassment has resulted in the claimant suffering a major depressive disorder.

There is a range of alternative management strategies that employers might take in an attempt to redress the situation. Some potential methods might include the following: the use and management of whistle-blowing mechanisms and the focus on support systems for those with grievances or on mediation methods ${ }^{23}$. Advice for human resources management includes staff training and other methods to curtail harassment, thereby avoiding associated costs altogether. Early and informal mediation could be deployed in which the parties are allowed to air their views; this may resolve grievances that would otherwise fester. For example, those against whom the complaint is made might be unaware of the impact of their action. If they are made aware of its effect, it is at least possible that they will recognise that their conduct has been objectionable and change their attitude. 
It is particularly important to safeguard an employer's legal position under the Protection from Harassment Act 1997, because, as highlighted earlier, unlike a legal action taken under the equality legislation by a claimant, there are no reasonable steps to defend vicarious liability under an action taken by a claimant under the PHA; thus, workplace measures to minimise the likelihood of litigation are particularly important in this domain. In particular, where a potential case of harassing behaviour arises in the workplace, an employer should do the following: a) consider acting on any known tendency that an alleged perpetrator has for aggression and abuse towards colleagues; b) heed or act upon the employee complaint of violent or abusive behaviour; c) consider the appropriateness of disciplinary action against the alleged perpetrator, and d) take any adequate steps necessary to protect the alleged victim from the alleged perpetrator, such as transferring the alleged perpetrator or victim to different work areas.

In summary, claims under the PHA tend to be based on an allegation of repeated and sustained behaviour based around personality of the victim/an/or work based issues that results in perceived abuse by the victim. Victims often claim to be suffering from severe depression as a result of the events.

It is evident from court judgments that employers must deal with claims of harassment more effectively so as to guard against litigation. Hunt et al. ${ }^{24}$ observe that if management allows a climate of disrespect to exist within an organisation, this makes it more likely for certain inappropriate behaviour to be taken for granted, and leads to the creation of an 'incivility spiral'. This is where discourteous behaviour becomes routine and regarded as normal by employees and employers ${ }^{25}$.

Human resource departments must adopt a more constructive and effective system for responding to harassment complaints. Individual employers need to identify the structural, organisational and cultural barriers that might impede an effective response to a complaint of harassment. Potent policies and practices need to be implemented for HR managers to curtail harassment and thus avoid the spectre of litigation. Porto ${ }^{26}$ stresses the need for strong policy statements and a strong code of conduct, in addition to clear reporting mechanisms and instant access to senior leaders who are empowered to take immediate action. Feblinger (2008) asserts that employer interventions need to create a positive organisational environment and decrease interpersonal mistreatment ${ }^{27}$.

24 Hunt, C.; Davidson, C.; Fielden, S., and Hoel, H. Sexual Harassment in the Workplace: A Literature Review. Equal Opportunities Commission, Working Paper series, No. 59. London, 2007.

25 Ibid.

26 Porto, G., and Lauve, R. Disruptive Clinician Behaviours: A Persistent Threat to Patient Safety. Patient Safety and Quality Health Care. 2006, July/August.

27 Feblinger, D.M. Incivility and Bullying in the Workplace and Nurses Shame Responses. Association of Women's Health, Obstetric and Neonatal. 2008, 37(2): 234-242. 
It is important for employers to note that under the PHA, damages can be recovered for anxiety falling short of an identifiable injury to health, i.e. injury to feelings. Such awards are not covered by the Employers Liability (Compulsory Insurance) Act $1969^{28}$ (Barrett, 2005, p. 264) ${ }^{29}$.

\section{Conclusion}

There are some important points for claimants and their representatives to consider in crafting a legal case of harassment either under anti-discrimination law or under the Protection of Harassment Act 1997, in order to maximise their chances of winning.

First, a claimant who has made a formal complaint to the employer prior to resorting to legal action tends to have a greater likelihood of success. This is a particularly interesting finding in the light of the research by Pollert ${ }^{30}$, who examined work-place grievances taken to Britain's employment tribunals. This research found that only $14 \%$ of workers who took legal action used formal grievance procedures in an attempt to avoid recourse to legal action. Furthermore, research about sexual harassment litigation by Lockwood et al. ${ }^{31}$ also observed that claimant chances of success were heightened if an internal complaint had been made prior to commencing legal action.

Second, claimants who obtained access to legal advice and resources at an early stage of the dispute process had a better chance of success. This finding is consistent with previous research by $\mathrm{Ozcan}^{32}$ into judicial outcomes of disability discrimination cases at appellate level. Good quality legal advice at an early stage in the process is a significant factor in aiding the construct of any subsequent court action.

Third, claimants who made additional complaints together with the harassment claim were less likely to win. In the mind of the EAT, the multiple claims undermined the credibility of the claimant and suggested that the litigation was unfounded and speculative in nature.

Fourth, claimants who had used the questionnaire procedure prior to taking legal action in the employment tribunal had a greater likelihood of success. The

28 Employers Liability (Compulsory Insurance) Act 1969, HMSO.

29 Barrett, B. The Protection of Harassment Act Enters the Workplace. Industrial Law Journal. 2005, 34: 261-269.

30 Pollert, A. Injustice at Work: How Britain's Low-Paid Non-Unionised Employees Experience Workplace Problems. Journal of Workplace Rights. 2008, 13: 223-244.

31 Lockwood, G.; Rosenthal, P., and Budjanovcanin, A. A Quantitative and Qualitative Analysis of Sexual Harassment Claims 1995-2005. Industrial Relations Journal. 2011, 42(1): 86-103.

32 Ozcan, K. A Judicial Analysis of the Disability Discrimination Act: A Windfall for Employers. Disability and Society. 2007, 22: 187-204. 
questionnaire procedure provides a claimant a crucial opportunity to gather the necessary evidence to prove his/her case. The evidence available to this study indicates that it is more difficult to win a harassment case where no questionnaire has been served. The recent decision by the conservative led coalition government to remove the questionnaire system is therefore cause for concern. It may well make it more difficult for claimants to establish harassment.

\section{References}

Aquino, K.; Grover, S.; Bradfield, M. The Effects of Negative Affectivity, Hierarchical Status, and Self-determination on Work place Victimization. Academy of Management Journal. 1999, 42: 260-72.

Aston, J.; Hill, D.; Tackey, N.D. The Experience of Claimants in Race Discrimination Employment Tribunal Cases. Employment Relations Series No.55, DTI London, 2006.

Barrett, B. The Protection of Harassment Act Enters the Workplace. Industrial Law Journal. 2005, 34: 261-269.

Deery, S.; Walsh, J., and Guest, D. Workplace Aggression: The Effects on Job Burnout and Turnover Intentions. Work, Employmemt and Society. 2013, 25(4): 742-759.

Einarsen, S. Bullying and Harassment at Work: Epidemological and Psychosocial Aspects. Doctoral dissertation. Department of Psychosocial Science, University of Bergen, 1996.

Einarsen, S.; Skogstad, A. Bullying at Work: Epidemiological Findings in Public and Private Organisations. European Journal of Work and Organization Psychology. 1996, 5(2): 185-201.

Equality and Human Rights Commission. Manifest for Change Progress Report. London, 2013.
Feblinger, D.M. Incivility and Bullying in the Workplace and Nurses Shame Responses. Association of Women's Health, Obstetric and Neonatal. 2008, 27(2): 234-242.

Frost, P.J. Toxic Emotions at Work. Boston, MA: Harvard Business School, 2003.

Glomb, T. M.; Liao, H. Interpersonal Aggression in Work Groups: Social Influence, Reciprocal and Individual Effects. Academy of Management Journal. 2003, 46(4): 486-705.

Hay, G. The Protection of Harassment Act 1997. 2012 [interactive]. [accessed on 07-09-2012]. <www.personneltoday. com/Articles/03/01/2012/58253/ Legal>.

Hoel, H.; Cooper, C. Destructive Conflict and Bullying at Work. Unpublished Report. Manchester: Manchester School of Management, Umist, 2000.

Hunt, C.; Davidson, C.; Fielden, S., and Hoel, H. Sexual Harassment in the Workplace: A Literature Review. Equal Opportunities Commission. Working Paper series, No. 59. London, 2007.

Ironside, M.; Seifert, R. Tackling Bullying in the Workplace: The Collective Dimension. In: S. Einarsen et al. (eds.). Bullying and Emotional Abuse in the Workplace: International Perspectives 
in Research Practice. London: Taylor and Francis, 2003, p. 383-398.

Keashly, L.; Jagatic, K. By Any Other

Name: American Perspectives on Workplace Bullying. In: S. Einarsen et al. (eds.). Bullying and Emotional Abuse in the Workplace: International Perspectives in Research and Practice. London: Taylor and Francis, 2003, p. 31-61.

Keen, S. Developments in the Law of Harassment. 2009 [interactive]. [accessed on 12-04-2012]. <www. pumpcourtcpd.com>.

Lamertz, L.M., and Aquino, K. Social Power, Social Status and Perceptual Similarity of Workplace Victimisation: A Social Network Analysis of Stratification. Human Relation. 2004, 57(7): 795-822.

Leymann, H. The Content and Development of Mobbing at Work. European Journal of Work and Organisational Psychology. 1996, 5(2): 165-184.

Liefooghe, A.; Mackenzie, K. Accounts of Workplace Bullying: The Role of the Organization. European Journal of Work and Organization Psychology. 2001, 10(4): 375-92.

Lockwood, G.; Rosenthal, P.; Budjanovcanin, A. A Quantitative and Qualitative Analysis of Sexual Harassment Claims 1995-2005. Industral Relations Journal. 2011, 42(1): 86-10.

Lockwood, G. A Legal Analysis of Sexual Harassment Tribunal Cases 19952005. International Journal of Law and Management. 2008, 50(6): 316-332.

Lopez, S.H.; Hodson, R., and Roscigno, V.J. Power Status and Abuse at Work: General and Sexual Harassment
Compared. Sociological Quarterly. 2009, 50(1): 3-27.

Ozcan, K. A Judicial Analysis of the Disability Discrimination Act: A Windfall for Employers. Disability and Society. 2007, 22: 187-204.

Pollert, A. Injustice at Work: How Britain's Low-Paid Non-Unionised Employees Experience Workplace Problems. Journal of Workplace Rights. 2008, 13: 223-244.

Porto, G., and Lauve, R. Disruptive Clinician Behaviours: A Persistent Threat to Patient Safety. Patient Safety and Quality Health Care. July/August, 2006.

Salin, D. Ways of Explaining Workplace Bullying: A Review of Enabling, Motivating and Precipitating Structures and Processes in the Work Environment. Human Relations. 2003, 56(10): 1213-1232.

Samani, K. Embracing New Directions in Workplace Bullying Research: A Paradigmatic Approach. Journal of Management Inquiry. 2012, 22(16): 26-36.

Spry, M. Workplace Harassment: What Is It, and What Should the Law Do About It. Journal of Industrial Relations. Australia: Sage, 1998, 40(2): 232-246.

Vartia, M. Consequences of Workplace Bullying with Respect to the Wellbeing of Its Targets and the Observers of Bullying. Scandinavian Journal of Work Environment Health. 2001, 27(1): 63-69.

Williams, K. Vicarious Liability of the Roman Catholic Church for Sexual Abuse by a Priest. Journal of Professional Negligence. 2010, 26: 113117. 


\title{
PRIEKABIAVIMAS DARBE: TEISINIS KONTEKSTAS
}

\author{
Graeme Lockwood \\ Londono universiteto Karališkasis koledžas, Didžioji Britanija \\ Vidushi Marda \\ Kristaus universiteto Teisès mokykla, Indija
}

\begin{abstract}
Anotacija. Straipsnyje analizuojamos priekabiavimo darbo santykiuose bylos, kurias nagrineja Anglijos tribunolai bei teismai. Atliekant tyrima demesys sutelkiamas $i$ ieškinius, susijusius su priekabiavimu, siekiant nustatyti veiksnius, sukeliančius teisinius padarinius, ir padèti bylos šalims konstruktyviai spręsti teisini konfliktą. Straipsnyje daromos išvados, kad žmogiškuju ištekliu padaliniai turi sukurti sistemas, leisiančias veiksmingiau reaguoti $i$ skundus dèl priekabiavimo. Darbdaviai turi identifikuoti struktūrinius, organizacinius bei kultūrinius barjerus, kurie ateityje gali sutrukdyti veiksminga reakcija $i$ skundus dèl priekabiavimo.
\end{abstract}

Reikšminiai žodžiai: darbdavys, darbo teise, priekabiavimas, teismu praktika, teisiné atsakomybé.

\section{HARASSMENT IN THE WORKPLACE: THE LEGAL CONTEXT}

\author{
Graeme Lockwood \\ King's College, London \\ Vidushi Marda \\ School of Law, Christ University
}

Summary. The occurrence of harassing behaviour in the work environment is a wellestablished problem in the modern workplace. Harassment manifests itself in different behaviours, such as social isolation, silent treatment, rumours, false accusations, threats, ridicule, name calling attacking the victim's private life or attitudes, excessive criticism, monitoring of work, withholding information or depriving responsibility and physical or verbal aggression. There is widespread evidence that harassing conduct can cause a wide range of psychological and work-related harm, including diminished work performance, lower job satisfaction, absenteeism, career interruptions, job loss, depression, and health problems. This article examines case law pursuant to antidiscrimination law and cases brought under the ambit of the Protection from Harassment Act 1997 (PHA, 1997) in the United Kingdom. Information on the flow of interpretive case law will no doubt continue to capture the attention of human resource and legal 
professions who need to be aware of potential legal liability in this domain. It is evident from the research that employers must deal with claims of harassment more effectively so as to guard against litigation. Human resource departments must adopt a more constructive and effective system for responding to harassment complaints. Individual employers need to identify the structural, organisational and cultural barriers that might impede an effective response to a complaint of harassment.

Keywords: employer, labour law, harassment, case law, legal liability.

Graeme Lockwood, Londono universiteto Karališkojo koledžo lektorius. Mokslinių tyrimų kryptys: darbo teisè, apimanti kolektyvinę bei individualią darbo teisę, diskriminacija dèl psichinès sveikatos, bylinèjimasis dèl seksualinio priekabiavimo, darbo konfliktai ir skundai dèl jų.

Graeme Lockwood, Lecturer in Law, King's College of London, University of London. Research interests: employment law, including both collective and individual employment law, mental health discrimination; litigation relating to sexual harassment; and workplace conflict and grievance.

Vidushi Marda, Kristaus universiteto Teisès mokyklos magistrantas. Mokslinių tyrimų kryptys: darbo teisè, nediskriminavimo teisė, intelektinè teisè, informacinių technologijų teisè, privatinè teisè.

Vidushi Marda, Final Year Law student at School of Law, Christ University, Bangalore, India. Research Interests: Employment Law, Anti Discrimination Law, Intellectual Property, Cyber Law, and Privacy Law. 